it for nearly three years recalls the daily talk with him (and one other colleague) about the work of yesterday and to-day, his irresistible sense of fun and extraordinary gift of sympathy, and his wise counsel and unfailing loyalty. It was easy to understand that in the Inns of Court O.T.C., where he had been a sergeant instructor, in the words of a comrade : "Recruits worshipped him, fellow N.C.O.'s loved him, officers valued and respected him".

In 1926 Deller visited the United States as the guest of the Laura Spelman Rockefeller Memorial. On his return he published under the title "Universities in the United States" some critical impressions which gained high praise in competent circles in America. He was deeply interested in American universities in relation to the community they serve; and the hospitality and friendship which he extended to visiting American scholars and administrators became proverbial. In 1927 he took a large part in the task of founding the British Institute in Paris; and up to the time of his death he served on the executive committee in London and on the educational committee, paying periodical visits to Paris and taking a keen interest in the progress of the Institute. $\mathrm{He}$ believed whole-heartedly in understanding and co-operation between France and Great Britain in general and between the universities of Paris and London in particular.

Many distinctions were conferred upon Sir Edwin Deller. One which he prized highly was his election as an honorary bencher of the Inner Temple in 1933. $\mathrm{He}$ was a fellow both of University College and of King's College. In 1932 he was made a Chevalier of the Legion of Honour "in recognition of his services in the cause of university relations between France and England". He was knighted in the New Year's Honours of 1935.

T.F.S.

\section{Prof. E. H. Kettle, F.R.S.}

The death of Prof. Kettle on December 1 is a serious loss to English pathology, coming as it has when he was at the height of his powers at the age of fifty-four years and when he had just got his department at the new British Postgraduate Medical School, London, well established and working productively. He was a London man, trained at St. Mary's Hospital, where he was afterwards on the teaching staff, going on to Cardiff in 1924, to St. Bartholomew's in 1927 and to his last post in 1934 : he was elected into the Royal Society this year.

With Kettle goes one more of the disappearing race of general pathologists which the current specialization no longer produces, and he was an expert in bacteriology as well as morbid anatomy and ready to tackle any problem experimentally. Besides the ordinary contributions to knowledge which come from most laboratory workers, he will be remembered for suggestive work on the variation of the local inflammatory response to different bacteria and especially for his investigation, started originally with Dr. W. E. Gye, on the poisonous action of silica on the tissues and its relation to tuberculosis.
This led him into the difficult field of industrial silicosis, which has in recent times turned out to be much more widespread and important than was at first supposed, and he showed clearly that it was the chemical character of the dusts rather than their mechanical irritation that determined the localization of tubercle bacilli which entered the body. Incidentally, he devised a very useful method of testing the potential danger of any industrial dust by animal experiment lasting a few weeks.

Hampered throughout life by a maimed leg and for the last ten years with recurrent and serious illness, Kettle never lost his buoyancy and his ready cheerfulness to teach his students and to guide young workers in the way they should go. He earned the respect of everyone and the affection of those who knew him well enough.

\section{Rev. J. Gordon Hayes}

The Rev. James Gordon Hayes, Vicar of Storridge, near Malvern, died on November 21 in his sixtieth year. He devoted much attention to a critical study of the records of polar exploration and was the author of four outstanding books on the subject. In "Antarctica", published in 1928, he dealt with the natural features of the Antarctic continent and the journeys of explorers during the first quarter of the twentieth century. It was the result of a great amount of reading and gave an important comparison of the methods and results of modern explorers. This was followed in 1932 by a more distinctively historical work "The Conquest of the South Pole", designed as a continuation of Dr. H. R. Mill's "Siege of the South Pole" and showing deeper appreciation of the personal qualities of explorers than was apparent in the earlier work. The other two books, relating to north polar exploration, were "Robert Edwin Peary", an endeavour to show the improbability of that explorer having reached the pole, and "The Conquest of the North Pole", a well-balanced summary of Arctic exploration in the twentieth century.

Mr. Gordon Hayes, who had been a civil engineer before he entered the Church and had taken honours in history at Cambridge, was engaged on a work on Napoleon as a statesman at the time when the progress of his fatal illness put a stop to his labours. He was a tireless worker, an enthusiastic seeker after truth in all quarters, and a warm friend of all interested in polar exploration, by whom his cheery companionship will be much missed. H. R. M.

We regret to announce the following deaths:

Dr. J. K. Fotheringham, F.B.A., reader in ancient astronomy and chronology in the University of Oxford, on December 12, aged sixty-two years.

Sir Herbert Jackson, K.C.B., F.R.S., formerly director of the British Scientific Instrument Research Association, on December 10, aged seventy-three years.

Dr. A. A. Robb, F.R.S., author of works on aspects of relativity, on December 14, aged sixty-three years. 